\title{
Principle of permanent sovereignty over natural resources in rulings of international courts
}

\section{Introduction}

Despite the fact of moving gradually away from the traditional energy sources, and reducing the share of the energy from the coal-fired power stations in the energy production, extraction of minerals other than hard coal remains crucial for human existence. It is enough to mention natural gas, metal ores, metals, gypsum, sand, precious stones, or thermal waters. However, it is necessary to keep in mind that geology and nature do not recognise the national boundaries, which results in the fact that some mineral deposits can be divided between two or more state territories. This leads to the situation when they are subject to the varied legal regimes. There is also a possibility of them being located outside the sovereignty or jurisdiction of any state.

There are still under-researched topics connected with mining. The aim of this study is to define legal issues related to cross-border mining, the so-called shared natural resources, and to present solutions to problems identified respectively. The second step, after analysis of the terms natural resources and shared natural resources, will involve an analysis of the principle of permanent sovereignty over natural resources in rulings of international courts. 


\section{Principles of the international law}

International environmental law is the fastest growing part of international law, partly because it equates environmental protection with a way to assure global security and peace. ${ }^{1}$ As in other ambits of international law, a subcategory of the principles of international environmental law can be distinguished here. $^{2}$

Of course, all problems related to the terms "principle" and "principle of law" in general should be kept in mind. The principles of international law often appear in international documents, but one must agree with L. Antonowicz that a fully authoritative, exhaustive and definitive catalogue of the basic principles of international law has not been created so far. ${ }^{3}$ The principles of international law are considered to be the basic, guiding principles in this system. ${ }^{4}$ However, according to the doctrine of environmental law, two categories of principles of international environmental law are distinguished. These are first of all general principles, among which are, for example, the principle of good neighbourliness and the principle of non-abuse of the law. These are obviously not strictly the principles of environmental law. However, their universal nature makes it possible to refer to this part of international law. The second category includes specific principles of international environmental law, among which the principle of sovereignty over natural resources can be mentioned.

\section{The essence and origins of the principle of sovereignty over natural resources}

Analysing the problem of the rights to the riches of the earth's core, we should first of all point to the principle of sovereignty over natural resources. This principle is derived from two other principles of public international

${ }^{1}$ See more: R. Rosicki: Ogólna charakterystyka międzynarodowego prawa ochrony środowiska. "Środkowoeuropejskie Studia Polityczne" 2010, p. 79; J. Ciechanowicz-McLean: Międzynarodowe prawo ochrony środowiska. Warszawa 2001.

2 J. Ciechanowicz-McLean: Międzynarodowe...

${ }^{3}$ L. Antonowicz: Podręcznik prawa międzynarodowego. Warszawa 2011, p. 38.

${ }^{4}$ A. WIŚnIewsKi: Zasady prawa międzynarodowego. In: Leksykon prawa międzynarodowego publicznego. 100 podstawowych pojęć. Eds. A. Przyborowska-Klimczak, D. Pyć. Warszawa 2012, p. 549. 
law, namely the self-determination of all nations and the sovereignty of states. ${ }^{5}$ It has now acquired the status of a principle of customary international law, as confirmed by the International Court of Justice, ${ }^{6}$ which will be further discussed in the article.

The subject to the principle of permanent sovereignty varies depending on a particular legal act. In some cases it is defined as states, in other cases - nations or peoples, in still other cases both of them. The following section presents the views of the doctrine in this aspect. The subject matter is also not fully specified, as such terms as: natural resources, natural riches and resources or natural riches are used. ${ }^{7}$ The differences and similarities between these terms have been analysed in my other works. ${ }^{8}$

In order to understand the essence of the principle of permanent sovereignty over natural resources, it seems necessary to briefly discuss its origins first. In its contemporary meaning, the principle in question appeared in the 1950s, although its roots can be traced back to medieval times, specifically, to concession agreements and capitulation treaties. Nowadays, two sources of the principle may be indicated - firstly, the economic development, especially of the so-called emerging economies, and secondly, international principles of the right to self-determination along with the pacta sunt servanda principle, and the concept of development cooperation. ${ }^{9}$ However, what hindered the universal implementation of the principle of permanent sovereignty over natural resources was its politicisation and the increasing conflict between developed and developing countries, which has its deep roots in the period of colonialism. ${ }^{10}$

The beginning of this principle in modern times were the resolutions of the United Nations General Assembly, passed in 1952..1 According to them, underdeveloped countries have the right to freely determine the use oftheir natural resources and should use them to ensure the implementation of

5 J. OsIEJEwICZ: Globalne zarzadzanie zasobami ropy i gazu w perspektywie prawnomiędzynarodowej. Warszawa 2018, p. 1.

${ }^{6}$ Case concerning Armed Activities on the Territory of the Congo (Dem. Rep. Congo v. Uganda), Report of Judgment, 2005 I.C.J. 168 (Dec. 19).

7 J. Osiejewicz: Globalne..., pp. 23-24.

${ }^{8}$ F. Nawrot: The legal concept of shared natural resources. "Polish Yearbook of Environmental Law" 2018, pp. 33-51.

9 J. Osiejewicz: Globalne..., p. 1.

${ }^{10}$ R. Andrzejczuk: Stała suwerenność nad zasobami i bogactwami naturalnymi. "Roczniki Nauk Prawnych" 1998 T. VIII, p. 5.

${ }^{11}$ Resolution of the United Nations General Assembly No 523 (VI), 12 January 1952 Integrated economic development and commercial agreements, https://documents-dds-ny.un.org/doc /RESOLUTION/GEN/NR0/067/78/IMG/NR006778.pdf?OpenElement and Resolution of the United Nations General Assembly No 626 (VII), 21 December 1952 Right to exploit freely natural wealth and resources, http://www.un.org/documents/ga/res/7/ares7.htm [accessed 4.09.2020]. 
their economic development plans. It was also recognised that the right of nations to freely dispose of their natural resources is intrinsic to their sovereignty and that UN Member States should refrain from acts that impede the exercise of sovereignty over natural resources by any State. ${ }^{12}$

Interestingly, at the design stage of these documents, as noted in the literature, initially the principle of sovereignty over natural resources was not assigned to states. ${ }^{13}$ This was because, with regard to human rights, the reference to the state, which would often be responsible for the inadequate realisation of the economic rights of individuals, seemed unjustified. ${ }^{14}$ Following the developments of decolonisation process, so resulting from purely political factors, the subject to the principle in question became the state, (by the same token) replacing "a nation" or "a people." Therefore, in later documents, it is not nations but states that are entitled by virtue of this principle. ${ }^{15}$ However, the content of some of the referred resolutions may suggest that for their authors, the right to freely exploit natural resources is an attribute of a people or nation, while its exercise belongs to the state, which should not be infringed upon by other members of the international community. ${ }^{16}$ If we assume after R. Andrzejczuk that the subject to the right to self-determination is a people or a nation, and that sovereign equality is only granted to states, it is finally possible to indicate the subjects entitled by virtue of the principle of sovereignty. According to the principle of self-determination, the right to dispose of resources and natural resources belongs to peoples and nations. And permanent sovereignty over these resources and riches is an attribute of the state, which in turn results from the principle of sovereign equality. ${ }^{17} \mathrm{~A}$ different view is represented by J. Osiejewicz, who states that in the UN General Assembly resolutions of the 1970s, the nation has lost its importance as an entity of the right to permanent sovereignty over natural resources. ${ }^{18}$

This principle was developed with the adoption of successive UN resolutions and acts of international law, including UN General Assembly Resolution 1803 (XVII) on permanent sovereignty over natural resources of 14 December 1962, ${ }^{19}$ Declaration on Social Progress and Development among the Main Conditions for Progress and Development of 11 December 1969, ${ }^{20}$

12 R. Andrzejczuk: Stała..., pp. 6-7.

13 Ibidem, p. 6.

${ }_{14}$ J. Makarczyк: Zasady Nowego Międzynarodowego Ładu Gospodarki Światowej. Wrocław 1988, p. 233.

${ }^{15}$ R. ANDRZEJCZuK: Stała..., p. 6.

16 Ibidem, p. 7.

17 R. ANDRZEJCZuK: Stała..., p. 14.

18 J. Osiejewicz: Globalne... p. 21.

${ }^{19}$ Resolution of the United Nations General Assembly No 1803 (XVII), Permanent sovereignty over natural resources, http://www.un.org/documents/ga/res/17/ares17.htm [accessed 4.09.2020].

${ }^{20}$ https://www.ohchr.org/Documents/ProfessionalInterest/progress.pdf [accessed 4.09.2020]. 
Resolution of the General Assembly of the United Nations of 18 December 1972 on the continuing sovereignty of developing countries over their resources, ${ }^{21}$ the Charter of Economic Rights and Obligations of States, which was adopted on 12 December 1974, ${ }^{22}$ Resolution 3201 (S-VI) - Declaration on establishing a new international economic order. It proclaimed, among other things, full permanent sovereignty of each state over its natural resources and all economic activities, including the right to nationalise its resources or transfer their ownership to its citizens. ${ }^{23}$

Since the 1970s, this principle has been incorporated into environmental documents for the first time in one of the most important acts in this field, the 1972 Declaration on the Human Environment, the so-called Stockholm Declaration, ${ }^{24}$ or the Rio Declaration on Environment and Development of 1992. ${ }^{25}$ Successive global environmental conferences, in particular the World Summit in Johannesburg in 2002 and the Conference on Sustainable Development Rio +20 in 2012 confirmed the principle of sovereignty over natural resources. ${ }^{26}$ In addition, the principle of continued sovereignty over natural resources has been incorporated into treaty law, notably for investment and environmental protection.

\section{The Principle of sovereignty - rights and obligations arising therefrom}

As J. Osiejewicz points out, for a long time the principle of permanent sovereignty over natural resources has been identified with the rights, yet no obligations, arising from it. ${ }^{27}$ However, N. Schrijver, after analysing the achievements to

${ }^{21} \mathrm{https}: / /$ undocs.org/en/A/RES/3016 (XXVII).

${ }^{22}$ Resolution of the United Nations General Assembly No 3281 (XXIX), Charter of Economics Rights and Duties of States, 12 December 1974, A/RES/29/3281, http://www.un-documents .net/a29r3281.htm [accessed 4.09.2020].

${ }^{23}$ J. Osiejewicz: Globalne..., p. 8.

${ }^{24}$ Declaration of the United Nations Conference on the Human Environment, Stockholm, $16 \mathrm{Ju}-$ ne 1972, http://www.unep.org/documents.multilingual/default.asp?documentid=97\&articleid=1503 [accessed 4.09.2020].

${ }^{25}$ United Nations Conference on Environment \& Development Rio de Janerio, Brazil, 3 to 14 June 1992, Agenda 21, https://sustainabledevelopment.un.org/content/documents/Agenda 21.pdf [accessed 4.09.2020].

26 J. Osiejewicz: Globalne..., p. 12.

${ }^{27}$ Ibidem, p. 25. 
date in this field, ${ }^{28}$ concluded that from the principle in question arise obligations, too. ${ }^{29}$

Following in N. Schrijver's footsteps, J. Osiejewicz distinguishes the rights arising from the principle of permanent sovereignty over natural resources:

1) the right to free disposal of natural resources;

2) the right to explore and exploit natural resources freely;

3 ) the right to recover effective control over natural resources and compensation;

4) the right to use natural resources for national development;

5) the right to manage natural resources in accordance with the national environmental policy;

6) the right to participate fairly in the benefits of transboundary natural resources management;

7) the right to regulate foreign investment;

8) the right to expropriate or nationalise foreign investment;

9) the right to settle disputes under national law. ${ }^{30}$

The rights indicated above obviously are associated with corresponding obligations:

1) the obligation to exercise permanent national sovereignty for the development and well-being of peoples;

2) the obligation to respect the rights and interests of indigenous peoples;

3) the obligation of international development cooperation;

4) the duty to protect and sustainably exploit natural resources and resources;

5) the obligation to share cross-border natural resources fairly;

6) the duty to respect international law and to treat foreign investors fairly;

7) the obligation relating to the right to take foreign ownership. ${ }^{31}$

The foregoing rights and obligations may be, according to J. Osiejewicz, grouped into five thematic areas, namely: management of natural resources, development of the country and prosperity of nations, environmental protection, international cooperation and investment protection. ${ }^{32}$ Of course, it is impossible to present within the framework of this study a detailed description of all

${ }^{28}$ See among others: R. Bernhardt: Encyclopedia of Public International Law, 12 Instalments. Amsterdam 1981-1990; R. HigGins: The taking of property by the state: recent developments in international law (T.176). In: Collected Courses of the Hague Academy of International Law. The Hague Academy of International Law, 1982; M. Dixon, R. McCorquodale: Cases and Materials on International Law. London 1995; J. Makarczyк: Principles of a New International Order: A Study of International Law in the Making. Dordrecht 1988; C. Brower: The Iran-United States Claims Tribunal. In: Recueil des Cours (1990-V), t. 224. Dordrecht 1993, pp. 127-396; A. Mouri: The International Law of Expropriation as Reflected in the Work of the Iran-US Claims Tribunal. Dordrecht 1994.

${ }^{29}$ N. SCHRIJVER: Sovereignty over Natural Resources. Cambridge 2008, pp. 258 ff.

30 J. Osiejewicz: Globalne..., p. 26.

${ }^{31}$ Ibidem.

${ }^{32}$ Ibidem. 
the previously mentioned rights and obligations resulting from the principle of permanent sovereignty over natural resources.

\section{The Judiciary}

The principle of permanent sovereignty over natural resources is also present in the case law of international courts and tribunals and international quasijudicial institutions. Examples include the rulings of the International Court of Justice or the Inter-American Commission and the Inter-American Court of Human Rights.

As regards the arbitration awards, for instance, following J. Osiejewicz, the Texaco judgment of $1978^{33}$ and the Liamco judgment of $1981,{ }^{34}$ which concerned the nationalisation of oil companies in Libya should be noted. Both of these judgments refer to the principle of permanent sovereignty over natural resources and one of the above mentioned resolutions, from 1962.

The principle has been accepted by the International Court of Justice, as is clearly reflected in the East Timor Case $^{35}$ and, in more recent times, Congo v. Uganda, which was mentioned at the beginning of this article (footnote 6) ${ }^{36} \mathrm{In}$ the latter case, the Court ruled that this principle is part of customary international law. Interestingly, this principle has also become the subject of human rights judgments. It pointed out in this judgment that the principle of permanent sovereignty over natural resources, as an element of customary law, also applies during the occupation. In other rulings, it also raised the issue of fisheries jurisdiction and delimitation of the continental shelf. In addition to the judgments as such, also in its advisory opinion, the Court pointed out that the human rights conventions do not cease to apply in times of armed conflict, at least for certain rights.

To address the issues relating to human rights further, it seems worthwhile to outline some decisions and judgements of the Inter-American Commission

${ }^{33}$ Sole arbitrator R.-J. Dupuy, Texaco Overseas Petroleum Co. and California Asiatic Oil Co. v. Government of Libyan Arab Republic, Judgment of 1977, reprinted in 17 ILM (1978), pp. 3-37, https://www.trans-lex.org/261700/_texaco-overseas-petroleum-company-v-the-govern ment-of-the-libyan-arab-republic-yca-1979-at-177-et-seq-/ [accessed 4.09.2020].

${ }^{34}$ Iran-United States Claims Tribunal, Libyan American Oil Company (LIAMCO) v. Government of Libyan Arab Republic, Revue de l'Arbitrage 1980, pp. 132 - 191, reprinted in 20 ILM 1981, p. 53, Judgment of 12 April 1977, https://www.trans-lex.org/261400 [accessed 4.09.2020].

${ }^{35}$ East Timor (Port. v Austrl.), 1995 I.C.J. 90 (June 30) (dissenting opinion of Judge Weeramantry).

${ }^{36}$ Case Concerning Armed Activities on the Territory of the Congo (Dem. Rep. Congo v. Uganda), Report of Judgment, 2005 I.C.J. 168 (Dec. 19). 
and the Inter-American Human Rights Tribunal, in the context of indigenous peoples' cases.

As it is indicated in the literature, the Inter-American System has collected an extensive track record in the area of resource allocation and use. This might sound odd in light of the fact that the Inter-American System does not include a right to natural resources as a human right per se. As will be shown below, however, it has managed to interpret individual rights and freedoms, including - but not limited to - the right to property, in such a way that domestic decisions on resource allocation and use can no longer disregard its mandates. Although a considerable proportion of its work and decisions deal with indigenous peoples, the resulting analyses and principles may have widespread applicability as they relate to the notion of individual well-being in connection with allocation of natural resources ${ }^{37}$ Further on, the author recalls following cases. A landmark case concerning resource use is the one dealing with a petition against the Government of Brazil filed by de Yanomami indigenous group in 1980. The petition originated in the government-sponsored occupation and mineral and agricultural development of an area of the Amazon and the Territory of Roraima where official demarcation of the borders of Yanomami lands was pending. After verifying that the Yanomarni's territory had been invaded by mining and farming interests that brought destruction to the group, the Commission concluded that "a liability of the Brazilian Government arises for having failed to take timely and effective measures to protect the human rights of the Yanomamis." 38

Next case, which directly concerns a state's disposition of natural resources, including land, pertains to the Maya indigenous communities of the Toledo District of Belize. The petitioners in that case complained that Belize granted logging and oil concessions of over half a million acres of land traditionally used and occupied by the Maya, in violation of those communities' human rights to property and equality. In ruling for the petitioners, the Commission made a significant statement regarding the breadth of protection granted to property rights under the Inter-American System in saying that "the organs of the InterAmerican human rights system have recognized that the property rights protected by the system are not limited to those property interests that are already recognized by states or that are defined by domestic law, but rather that the right to property has an autonomous meaning in international human rights law." The Commission further states that "development activities must be accompanied by appropriate and effective measures to ensure that they do not proceed at

${ }^{37}$ L. BARRERA-HeRnÁNDEZ: Sovereignty over Natural Resources under Examination: The Inter-American System for Human Rights and Natural Resource Allocation. "Annual Survey of International \& Comparative Law" 2006, V. 12, Issue 1, p. 49.

${ }^{38}$ Inter-American Commission on Human Rights, Res. 12/85, Case 7615, Brazil, March 5, 1985, Recommendation \#11. 
the expense of the fundamental rights of persons who may be particularly and negatively affected." 39

Also of importance in this context is the Dann v. United States case (also known as Western Shoshone Case) decided and published by the Inter-American Commission in 2002. At issue in this case was the right of the indigenous petitioners to access and use traditional (allegedly public) lands and resources for livestock grazing and gathering of subsistence foods. In denying access, the United States argued that indigenous title to the lands in question had been extinguished as a result of the occupation of the West by non-indigenous settlers (inverse condemnation). The Commission determined that the procedure set up by the U.S. to decide on indigenous land claims which resulted in the alleged extinction of the petitioners' rights was defective, lacking the requisites of fully informed and mutual consent that are fundamental to the protection of the human right to property. As a result, the Commission concluded that the United States had "failed to ensure the Dann's right to property under conditions of equality in connection with their claims to property rights in the Western Shoshone ancestral lands." ${ }^{40}$

An already quoted herein N. Schrijver draws attention to rulings of the InterAmerican Court of Human Rights. ${ }^{41}$ In the Mayagna (Sumo) Awas Tingni Community v. Nicaragua case, the Court interpreted the notion of property to include indigenous peoples' communal land tenure. However, the Court did not use the concept of the sovereign right to control and exploit natural resources. Under international human rights law, the rights of indigenous peoples with regard to their traditional lands and the natural resources are inextricably linked to the right to enjoy their culture and to preserve their identity and natural environment. Such rights take shape in particular through participatory rights rather than through sovereign rights. ${ }^{42}$

This finding has been confirmed and elaborated in various later decisions by the Inter-American Commission and Court, including in cases of the Saramaka People v. Suriname (2007). ${ }^{43}$ In the latter judgement, the Inter-American Court of Human Rights concluded that Article 21 of the American Convention, interpreted in the light of the rights recognised under common Article 1 of the two

39 Inter-American Commission on Human Rights, Report No. 40/04, Case 12.053, Merits, May a Indigenous Communities of the Toledo District. Belize, Oct. 12, 2004, para. 117 and para. 150 .

40 OAS, Report No. 75/02, Case 11.140, Mary and Carrie Dann-United States, Dec. 27, 2002.

41 N. SCHRIJVER: Self-determination of peoples and sovereignty over natural wealth and resources. In: Realizing the Right to Development. United Nations Publication, New York 2013.

42 Inter-American Court of Human Rights, Mayagna (Sumo) Awas Tingni Com-munity v. Nicaragua, judgement of 31 August 2001.

43 Inter-American Court of Human Rights, Saramaka People v. Suriname (judgement of 28 November 2007), para. 95. 
International Covenants and Article 27 of the International Covenant on Civil and Political Rights on the rights of persons belonging to minorities, grants to the members of the Saramaka community the right to enjoy property in accordance with their communal tradition. The Court also concluded that "Article 21 of the Convention should not be interpreted in a way that prevents the State from granting a type of concession for the exploration and extraction of the natural resources within the Saramaka territory." Rather, the State must observe safeguards and ensure effective participation and reasonable benefit in order to pre-serve the rights of the Saramaka people. The Court concluded that Suriname had not complied with these safeguards and thus had violated Article 21 of the Convention, in conjunction with common Article 1 of the International Covenants, to the detriment of the Saramaka people. Therefore, the Court ordered in particular that the "State shall adopt legislative, administrative and other measures necessary to recognize and ensure the right of the Saramaka people to be effectively consulted, in accordance with their traditions and customs, or when necessary, the right to give or withhold their free, informed and prior consent, with regards to development or investment projects that may affect their territory, and to reasonably share the benefits of such the members of the Saramaka people, should these be ultimately carried out."

In the more recent decision of Kichwa Indigenous People of Sarayaku v. Ecuador, the Court assessed whether Ecuador had violated the property rights of the Kichwa people of Sarayaku by awarding a private company an oil exploration and exploitation concession which partially covered ancestral lands, without a consultation process or their free, prior and informed consent. The InterAmerican Court found that Ecuador had violated Article 21 of the American Convention, although it did not elaborate further on the obligations to consult and to obtain consent in the context of large-scale extractive industry projects that impact on indigenous territories. ${ }^{44}$

Similar cases have been looked at by the African Commission, as in the context of the principle of permanent sovereignty over natural resources in the case concerning the self-determination of the Ogoni people in the Nile delta in 2001. The African Commission found that Nigeria had violated several articles of the African Charter and appealed to the government to ensure protection of the environment, health and livelihood of the Ogoni people. It did this by, inter alia, ensuring compensation to victims of human rights violations - including relief and resettlement assistance to victims of government raids - and undertaking a comprehensive clean-up of lands and rivers damaged by oil operators.

${ }^{44}$ Kichwa Indigenous People of Sarayaku v. Ecuador [2012] Inter-Am Court HR (ser C) No 245 . 


\section{Conclusions}

Summing up the considerations made in this paper, the most important issues should be highlighted. The principle of permanent sovereignty over natural resources derives from the principle of self-determination of peoples and the principle of national sovereignty. Its development dates back to the second half of the 20th century and is now recognised as one of the principles of international environmental law. However, the problem in shaping this principle was its politicisation and the growing conflict between developed and developing countries, which has its deep roots in the period of colonialism.

The right to dispose of resources and natural resources belongs to peoples and nations. The permanent sovereignty over these resources and riches is an attribute of the state, which in turn results from the principle of sovereign equality. In turn, the subject of this principle are natural resources and natural riches.

It should also be borne in mind that not only powers but also corresponding duties are connected with it. They can be grouped into five separate thematic areas, namely: management of natural resources, development of the country and prosperity of nations, environmental protection, international cooperation and investment protection.

Analysis of the rulings proves, that the principle of permanent sovereignty over natural resources is also present in the case law of international courts and tribunals and international quasi-judicial institutions. The principle has been accepted by the International Court of Justice, interestingly, this principle has also become the subject of human rights judgments.

\section{Literature}

ANDRZejCzuk R.: Stała suwerenność nad zasobami i bogactwami naturalnymi. "Roczniki Nauk Prawnych" 1998 T. VIII.

Antonowicz L.: Podręcznik prawa międzynarodowego. Warszawa 2011.

Barrera-Hernández L.: Sovereignty over Natural Resources under Examination: The Inter-American System for Human Rights and Natural Resource Allocation. "Annual Survey of International \& Comparative Law” 2006, V. 12, Issue 1.

Bernhardt R.: Encyclopedia of Public International Law, 12 Instalments. Amsterdam 19811990.

Brower C.: The Iran-United States Claims Tribunal. In: Recueil des Cours (1990-V), t. 224. Dordrecht 1993.

Ciechanowicz-McLean J.: Międzynarodowe prawo ochrony środowiska. Warszawa 2001. 
Dixon M., McCorquodale R.: Cases and Materials on International Law. London 1995.

HigGins R.: The taking of property by the state: recent developments in international law (T.176). In: Collected Courses of the Hague Academy of International Law. The Hague Academy of International Law, 1982.

Makarczyk J.: Principles of a New International Order: A Study of International Law in the Making. Dordrecht 1988.

MakARCZYK J.: Zasady Nowego Międzynarodowego Ladu Gospodarki Światowej. Wrocław 1988.

Mouri A.: The International Law of Expropriation as Reflected in the Work of the Iran-US Claims Tribunal. Dordrecht 1994.

OsIEJEwICz J.: Globalne zarzadzanie zasobami ropy i gazu w perspektywie prawnomiędzynarodowej. Warszawa 2018.

Rosicki R.: Ogólna charakterystyka międzynarodowego prawa ochrony środowiska. "Środkowoeuropejskie Studia Polityczne" 2010.

SCHRIJVER N.: Self-determination of peoples and sovereignty over natural wealth and resources. In: Realizing the Right to Development. United Nations Publication, New York 2013.

SCHRIJVER N.: Sovereignty over Natural Resources. Cambridge 2008.

WiśNIEWSKi A.: Zasady prawa międzynarodowego. In: Leksykon prawa międzynarodowego publicznego. 100 podstawowych pojęć. Eds. A. Przyborowska-Klimczak, D. Pyć. Warszawa 2012.

Filip Nawrot

\section{Zasada stałej suwerenności nad zasobami naturalnymi w orzecznictwie sądów międzynarodowych}

\section{Streszczenie}

Celem tego artykułu jest przedstawienie zasady stałej suwerenności nad zasobami naturalnymi w orzecznictwie sądów międzynarodowych. Opracowanie to jest kontynuacją zagadnień omówionych w poprzednich artykułach dotyczących górnictwa transgranicznego i tzw. zasobów naturalnych dzielonych. Do opracowania tego tematu wykorzystano literaturę polską i zagraniczną, a przede wszystkim orzecznictwo sądów międzynarodowych.

W pierwszej części niniejszego artykułu przedstawiono teoretyczne podstawy konieczne do dalszych rozważań. Zawiera ona definicje oraz podstawy zasady stałej suwerenności nad zasobami naturalnymi. Druga część opisuje najbardziej istotne prawa i obowiązki wynikające z omawianej zasady. Na koniec zaprezentowano analizę orzeczeń sądów międzynarodowych w odniesieniu do zasady stałej suwerenności nad zasobami naturalnymi oraz wnioski wynikające z tej analizy.

Słowa kluczowe: zasada stałej suwerenności, zasoby naturalne, orzecznictwo sądów międzynarodowych 
Филип Наврот

\title{
Принцип постоянного суверенитета над природными ресурсами в практике международных судов
}

\author{
Резюме
}

Несмотря на общемировую тенденцию отказа от традиционных источников энергии и сокращения доли угольных электростанций в производстве энергии, добыча других полезных ископаемых, помимо угля, по-прежнему остается основой существования человека. Тем не менее, остается еще много не до конца изученных вопросов, связанных с горнодобывающей промышленностью. Основная цель этого исследования - определить правовые проблемы, связанные с трансграничной добычей полезных ископаемых и так называемыми разделяемыми природными ресурсами, а также представить решения выявленных проблем. Следующим этапом после анализа понятий природных ресурсов и разделяемых природных ресурсов, используемых в предыдущих работах, является анализ принципа постоянного суверенитета над природными ресурсами в судебной практике международных судов.

В первой части статьи представлены теоретические основы, необходимые для дальнейших рассуждений. Она содержит определение и основы принципа постоянного суверенитета над природными ресурсами. Во второй части описаны наиболее важные права и обязанности, вытекающие из обсуждаемого принципа. В завершение представлены анализ решений международных судов в отношении принципа постоянного суверенитета над природными ресурсами и выводы, сделанные на основе этого анализа.

Ключевые слова: принцип постоянного суверенитета, природные ресурсы, судебная практика международных судов

Filip Nawrot

\section{II principio della sovranità permanente sulle risorse naturali nella giurisprudenza dei tribunali internazionali}

\author{
Sommario
}

Riassunto: Lo scopo di questo articolo è di stabilire il principio della sovranità permanente sulle risorse naturali nella giurisprudenza dei tribunali internazionali. Questo argomento è in linea con le questioni discusse in precedenti lavori riguardanti l'estrazione mineraria transfrontaliera e le cosiddette risorse naturali condivise. La letteratura polacca e straniera e, soprattutto, la giurisprudenza dei tribunali internazionali sono state utilizzate per sviluppare questo argomento.

La prima parte di questo articolo fornisce le basi teoriche necessarie per ulteriori approfondimenti. Contiene definizioni e basi per il principio della sovranità permanente sulle risorse naturali. La seconda parte descrive i diritti e gli obblighi più importanti derivanti da questo principio. Infine, viene presentata un'analisi delle sentenze dei tribunali internazionali in relazione al principio della sovranità permanente sulle risorse naturali, nonché le conclusioni che ne derivano.

Parole chiave: il principio della sovranità permanente, le risorse naturali, la giurisprudenza dei tribunali internazionali 